ks. Józef Makselon

Uniwersytet Papieski Jana Pawła II w Krakowie

\title{
Psychologiczne wątki w encyklice Lumen fidei
}

Kolejna encyklika, jaką otrzymujemy w czasie niewątpliwego przełomu w myśleniu o papiestwie, kiedy następuje niespodziewana i historycznie znacząca rezygnacja papieża, jest wyjątkowo profetyczna. Rozpoznając znaki czasu i fizyczne możliwości towarzyszenia współczesnemu człowiekowi w jego drodze do wiary, Benedykt XVI pozostawił swojemu następcy pewne przemyślenia $\mathrm{i}$ inspiracje teologiczne, dzięki którym mogła powstać encyklika na temat wiary. Wpisała się ona w Rok Wiary i w zasadniczy sposób zamyka zamierzoną przez Benedykta XVI teologiczną trylogię. Rozpoczęła ją encyklika Spe salvi, gdzie odnajdziemy bardzo ciekawe analizy kondycji współczesnego człowieka, przed którym radykalnie zamyka się perspektywa przyszłości, ale także ważne propozycje usensownienia biegu dziejów i osobistej historii. Zaś w kolejnej encyklice Deus caritas est Benedykt XVI w mistrzowski sposób dotyka kolejnego wymiaru ludzkiej egzystencji i wskazuje na rozmaite implikacje przykazania miłości w życiu indywidualnym i społecznym. Na tym tle encyklika Lumen fide $i^{1}$ stanowi swoiste podsumowanie refleksji o religijności współczesnego człowieka. Koncentruje się ona przede wszystkim na argumentacji teologicznej. Jak wiadomo, owa argumentacja odwołuje się również do ustaleń innych dyscyplin naukowych i dlatego powinna być (i niestety tylko niekiedy jest) wpisana we współczesną filozofię człowieka. Ta zaś (jeśli jest racjonalna) winna uwzględniać osiągnięcia innych poszukiwań (np. psychologii). W tym kontekście uzasadnione jest zatem pytanie o wątki psychologiczne w encyklice Lumen fidei. Dotyczą one głównie źródeł religijności, jej dynamiki oraz funkcjonowania światła wiary.

W encyklice Lumen fidei wiele razy powraca się do pytania o powody, przyczyny, motywacje akceptacji czy aprobaty jakkolwiek rozumianego absolutu. W tym zakresie poglądy, hipotezy oraz wyniki badań empirycznych (jak zawsze probabilistyczne) nie są jednoznaczne. Niemniej jednak wskazują one na określone kierunki interpretacji.

\footnotetext{
${ }^{1}$ Papież Franciszek, enc. Lumen fidei, Watykan 2013 [dalej: LF].
} 
W związku z tym, ogólnie pozytywnym, przesłaniem analizowanego dokumentu (światło tak się właśnie kojarzy) w niniejszym opracowaniu zwraca się uwagę przede wszystkim na pozytywne funkcje religijności.

\section{Fenomen światła}

W encyklice możemy prześledzić interesujące odniesienia do fenomenu czy fenomenologii światła. Jego przeciwieństwem jest tzw. archetyp cienia. W psychologii Carla Gustava Junga oznacza on negatywną stronę ludzkiej psychiki, wywodzącą się z instynktów „zwierzęcych”. Znawca tego problemu zauważa, że próby „rozwiązania problemu Cienia opierają się na iluzyjnych, idealistycznych, nierealnych podstawach. Konkretyzacja Cienia wyzwala bazujący na lęku mechanizm błędnego koła (lęk przed lękiem)"2.

Kontrastuje z tym rzeczywistość wiary, kojarzona właśnie ze światłem przyniesionym przez Chrystusa. W pierwszym zdaniu encykliki czytamy: „Światło wiary: tym wyrażeniem tradycja Kościoła nazwała wielki dar przyniesiony przez Jezusa, który tak oto przedstawia się w Ewangelii św. Jana: «Ja przyszedłem na świat jako światłość, aby nikt, kto we Mnie wierzy, nie pozostawał w ciemności» $(12,46)$ ”.

Świat pogański - choć spragniony światła i kojarzący go z ubóstwianym słońcem - stawał jednak bezradny wobec mroku, jaki spowijał ziemię po jego zachodzie. Dopiero kosmiczne wydarzenie wcielenia i odkupienia rozproszyło mroki ludzkiej egzystencji.

Odnosząc się do obecnego we współczesnej filozofii nurtu nietzscheańskiego, kontestującego tradycyjne myślenie religijne, papież dochodzi do wniosku, że długa droga rozwoju (starć czy konfliktów związanych z przejmowaniem przez rozum funkcji światła) ostatecznie prowadzi do klęski, gdyż rozum może być potraktowany jedynie jako światełko, a nie ostateczne opromienienie ludzkiego istnienia. Znamienne pod tym względem są następujące zdania encykliki:

Pojmowano więc wiarę jako ucieczkę spowodowaną przez brak światła, pod wpływem ślepego uczucia, albo jako subiektywne światło, zdolne być może rozpalić serce, dostarczyć prywatnej pociechy, ale którego nie można zaproponować innym jako obiektywne, wspólne światło oświecające drogę. Stopniowo dostrzegano jednak, że światło autonomicznego rozumu nie potrafi wystarczająco rozjaśnić przyszłości; w końcu kryje się ona w mroku i pozostawia człowieka z lękiem przed nieznanym. I tak człowiek zrezygnował z poszukiwania wielkiego światła, by zadowolić się małymi światełkami, które oświecają krótką chwilę, ale są niezdolne do otwarcia

${ }^{2}$ Z. W. Dudek, Podstawy psychologii Junga. Od psychologii głębi do psychologii integralnej, Warszawa 2002, s. 247. 
drogi. Gdy brakuje światła, wszystko staje się niejasne, nie można odróżnić dobra od zła, drogi prowadzącej do celu od drogi, na której błądzimy bez kierunku³.

Światło zatem jest „właściwą cechą wiary”. Ma ono szczególny charakter, ponieważ ,jest zdolne oświetlić całe życie człowieka"

Powyższy fragment odsyła także do zagadnienia roli (funkcji) religijności w życiu człowieka. Można też postawić pytanie o źródła dynamiki religijnej wiary.

\section{Dynamika wiary}

Dynamika wiary jest dla papieża oczywistością. Świadczą o tym następujące zdania:

Kościół nie zakłada bowiem nigdy wiary jako faktu oczywistego, lecz jest świadomy, że ten Boży dar trzeba karmić i umacniać, by nadal wskazywał mu drogę. Sobór Watykański II ukazał blask wiary w ludzkim doświadczeniu, przemierzając tym samym drogi współczesnego człowieka. W ten sposób stało się jasne, że wiara ubogaca ludzkie istnienie we wszystkich jego wymiarach ${ }^{5}$.

Na ten aspekt wiary zwracają też uwagę psychologowie rozmaitych orientacji teoretycznych wskazując, że religijność wpisuje się rozmaite pokłady ludzkiej psychiki. Głównie wskazuje się na funkcje emocjonalne, poznawcze i społeczne. Gratyfikacja potrzeby bezpieczeństwa jest jedną z podstawowych, uwzględnianych w każdej wielkiej propozycji religijnej potrzeb. Wierząc w bezgraniczną miłość, która nie uchyla się od śmierci, człowiek przezwycięża wszelkie podejrzenia i pozwala w pełni zawierzyć się Chrystusowi. Zauważmy, że „Bóg jest nie tylko transcendentny, ale pozostaje z człowiekiem w relacjach immanentnych. W związku z tym jest możliwa gratyfikacja potrzeby bliskości i skorelowanej z nią intymności”'.

Dojrzała wiara pomaga w pokonywaniu trudności i wzmacnia tzw. dobrostan psychiczny. Wśród psychologów religii panuje dość powszechne przekonanie, że religijność ma znaczenie stabilizujące i sensorodne?.

\footnotetext{
${ }^{3}$ LF 3 .

${ }^{4} \mathrm{LF} 4$.

${ }^{5}$ LF 6.

${ }^{6} \mathrm{~J}$. Makselon, Psychologiczne funkcje religijności, [w:] Religia we współczesnej Europie. Religion im gegenwärtigen Europa, red. ks. J. Dziedzic, Kraków 2008, s. 235.

${ }^{7}$ Zob. K. I. Pargament, The psychology of religion and coping: theory, research, practice, New York 1997; P. S. Fry, Religious involvement, spirituality and personal meaning for life: existential predictors of psychological well-being in community-residing and institutional care elders, „Aging and Mental Health" 4 (2000), s. 375-387; M. F. Steger, P. Frazie, Meaning in life: one link in the
} 


\section{W encyklice czytamy:}

Duch Święty przemienia nas, oświeca drogę przyszłości i sprawia, że rosną w nas skrzydła nadziei, byśmy przemierzali tę drogę z radością. Wiara, nadzieja i miłość w godnym podziwu połączeniu kierują życie chrześcijańskie do pełnej komunii z Bogiem8.

Intelektualne zbliżenie się do zrozumienia wiary jest możliwe, gdy zagłębiamy się w opowiadanie o jej historii w wymiarze społecznym, jak również indywidualnym. Nabiera ona nowego znaczenia poprzez usłyszenie Bożego słowa w kontekście wezwania do osobistej odpowiedzi.

Dlatego Bóg nie jest Bogiem jakiegoś miejsca ani nawet Bogiem związanym z jakimś specyficznym świętym czasem, ale jest Bogiem osoby, Bogiem właśnie Abrahama, Izaaka i Jakuba, zdolnym do nawiązania kontaktu z człowiekiem i do ustanowienia z nim przymierza. Wiara stanowi odpowiedź na Słowo skierowane do osoby, daną pewnemu „Ty”, które nas woła po imieniu?.

Powyższa konstatacja jest bardzo ważna, gdyż wskazuje na znaczenie obrazu Boga w konstytuowaniu się wiary. Wezwanie i obietnica aktywizujące się w akcie wiary wyraźnie wskazują na styl komunikowania się Boga z człowiekiem i specyficzną interakcyjność. Dotykamy tutaj fundamentalnej kwestii obrazu Boga i możliwych form bałwochwalstwa.

Zostało ono precyzyjnie nazwane w papieskim dokumencie.

Z bałwochwalstwem mamy do czynienia wówczas, ,gdy zwraca się pełne szacunku oblicze do oblicza, które nie jest obliczem". Zamiast wierzyć w Boga, człowiek woli czcić bożka, którego oblicze można utrwalić i którego pochodzenie jest znane, bo został przez nas uczyniony. W przypadku bożka nie ma niebezpieczeństwa ewentualnego powołania, które wymagałoby wyrzeczenia się własnego poczucia bezpieczeństwa, ponieważ bożki „mają usta, ale nie mówią” (Ps 115, 5). Rozumiemy więc, że bożek jest pretekstem do tego, by postawić samych siebie w centrum rzeczywistości, adorując dzieło własnych rąk. Człowiek, gdy traci zasadnicze ukierunkowanie, które spaja jego życie, gubi się w wielorakości swoich pragnień.

Dlatego bałwochwalstwo jest zawsze politeizmem, poruszaniem się bez celu od jednego pana do drugiego. Bałwochwalstwo nie wskazuje jednej drogi, lecz wiele szlaków, które nie prowadzą do wyraźnego celu, a raczej tworzą labirynt ${ }^{10}$.

chain from religiousness to well-being, „Journal of Counseling Psychology” 52 (2005), s. 574-582;

D. Krok, Religijność a jakość życia w perspektywie mediatorów psychospołecznych, Opole 2009.

${ }^{8}$ LF 7.

${ }^{9}$ LF 8.

${ }^{10}$ LF 13. 
Trzeba w tym miejscu dodać, że prawdziwa wiara jest przeciwieństwem bałwochwalstwa, ponieważ łączy się z permanentnym odwracaniem się od rozmaitych bożków i wchodzeniem w przestrzeń otwartą przez żywe słowo Boże. Powierza się ona ,miłosiernej miłości, która zawsze przyjmuje i przebacza, wspiera i ukierunkowuje egzystencję, okazuje się potężna w swej zdolności prostowania wypaczeń naszej historii"11.

Pomijając szczegółowe typologie obrazu Boga warunkującego dynamikę wiary, zwróćmy uwagę na personalną wizję Boga, który jawi się człowiekowi jako Osoba i podejmuje z nim osobowe relacje ${ }^{12}$. Możliwość bycia z Bogiem jako osobą wyklucza traktowanie Go jak idola i pozwala wyzbyć się pokusy formalizmu moralnego. W innym przypadku (pojmowanie Boga jako ,instancji” bardziej regulującej porządek aniżeli inspirującej do rozwoju) obserwujemy zagubienie człowieka i bezowocność tak pojmowanej wiary. Ważny w tym kontekście jest następujący fragment encykliki:

Taki człowiek, nawet jeśli zachowuje przykazania, nawet jeśli pełni dobre uczynki, stawia w centrum siebie i nie uznaje, że źródłem dobroci jest Bóg. Kto tak postępuje, kto chce być źródłem własnej sprawiedliwości, widzi, że szybko ona się wyczerpuje, oraz odkrywa, że nie może nawet dochować wierności prawu. Zamyka się w sobie, izolując się od innych, a przede wszystkim od Pana, dlatego jego życie staje się daremne, jego uczynki jałowe, jest niczym drzewo z dala od wody ${ }^{13}$.

Krótkie zdanie encykliki, że „wiara Abrahama będzie zawsze aktem pamięci”"14, zwraca uwagę na szczególny aspekt poznawczy w doświadczaniu wiary. Jak wiadomo, jedną z funkcji poznawczych człowieka jest pamięć. W psychologii przyjmuje się najogólniej, że jest to ,umysłowa funkcja przechowywania informacji o bodźcach, zdarzeniach, obrazach, ideach itp., kiedy pierwotnie działające bodźce nie są już obecne" 15 .

Wielorakie funkcje pamięci mają oczywiste odniesienie do narracji o wierze, jak również o jej możliwych modyfikacjach czy zniekształceniach, co z kolei wiąże się ze społecznym spostrzeganiem i możliwymi deformacjami w tym względzie. W encyklice pamięć jest rozumiana jednak nieco inaczej; można nawet powiedzieć, że zyskała ona nową semantykę. Czytamy bowiem, że pamięć w kontekście wiary odnosi się też do przyszłości. Papież pisze: „Jednak ta pamięć, będąc pamięcią o obietnicy, nie zamyka się w przeszłości, staje się zdolna otworzyć na przyszłość, oświecić przemierzaną drogę"

${ }^{11}$ LF 13

${ }_{12}$ Zob. R. Jaworski, W nurcie badań dotyczacych obrazu Boga, „Zeszyty Naukowe KUL” 41 (1998) nr 3-4, s. 217-225.

${ }^{13}$ LF 19.

${ }^{14}$ LF 9.

${ }^{15}$ A. S. Reber, Stownik psychologii, Warszawa 2000, s. 78.

${ }^{16}$ LF 9. 
Wydaje się, że tak rozumiana pamięć bliższa jest wyobraźni. W wyobraźni bowiem - wykorzystując zarejestrowane fakty - konstruujemy jakąś sekwencję (wizję) możliwych zdarzeń. Na marginesie tej obserwacji warto wskazać, że dobrze byłoby też mówić o wyobraźni wiary na podobieństwo słynnego już sformułowania Jana Pawła II odnoszącego się do wyobraźni miłosierdzia.

Dynamizm wiary jest uwarunkowany wieloczynnikowo. Wszelkie analizy religioznawcze (religiologiczne) zmierzają do tego, aby wykazać w pewnym sensie „niedokończoność” procesu zawierzania i wiary. Wiarę dynamizują wielkie pytania. Podobnie jak w psychologii współczesnej stawia się wielkie pytania $^{17}$, tak również w poszukiwaniu jej współczesnej wersji wskazuje się na potrzebę „zracjonalizowania” wiary przez odniesienie jej do bardzo ważnych pytań aksjologicznych. Chodzi szczególnie o pytania na temat człowieka: kim jest, jakie są podstawowe motywy skłaniające go do takich a nie innych wyborów. Pytamy też o wymiar relacyjności interpersonalnej w doświadczeniu religijnym. W tym kontekście koniecznie trzeba zwrócić uwagę na oddziaływanie świata wirtualnego na mentalność współczesnych ludzi, którzy - w znaczącym procencie przypadków - przejawiają tendencję do ucieczki w bezosobowy świat. Można nawet powiedzieć o swoistym lęku przed twarzą człowieka. Rodzi to określone skutki psychologiczne i religijne. Utrudnia bowiem doświadczenie wspólnotowego i autentycznego przeżywania daru wiary. Wiara zaś - jak wiadomo - rozkwita przez uczestnictwo. Uczestnicząc, człowiek uczy się wiary. Sproblematyzowanie i zanik zdolności do uczestnictwa jest zagrożeniem nie tylko dla rozwoju osobowego, lecz także dla przeżywania wiary ${ }^{18}$. Odrębnym zagadnieniem jest sposób i tempo uczenia się uczestnictwa. Zależy to od wielu skomplikowanych uwarunkowań środowiskowych oraz osobowościowych ${ }^{19}$.

Modne współcześnie analizy tzw. narracji w psychologicznej analizie ludzkich zachowań rodzą też rozmaite refleksje. Wiele z owych narracji, które miały mieć istotne znaczenie dla zrozumienia człowieka i świata, uległo dewaluacji bądź okazało się nieudanym sposobem podejścia do aktualnych zagadnień kulturowych $\mathrm{i}$ antropologicznych ${ }^{20}$. Mijają się one w wielu przypadkach z prawdą o człowieku objawioną przez miłującego Boga.

Papież polemizuje z tezą, jakoby miłość nie mogła się wiązać z prawdą i zauważa, że „miłość jawi się dziś jako doświadczenie, związane ze światem niestałych uczuć,

${ }^{17}$ Por. W. Łukaszewski, Wielkie pytania psychologii, Gdańsk 2003.

${ }^{18}$ Por. P. Kawalec, Od świata wirtualnego do świata osób. Spoleczeństwo informacyjne a wyzwania i zagrożenia dla uczestnictwa, „Ethos” 18 (2005) z. 1-2, s. 163-183.

${ }^{19}$ Zob. E. C. Sites, F. L. Garzon, F. A. Milacci, B. Boothe, A phenomenology of the integration of faith and learning, ,Journal of Psychology and Theology” 37 (2009), s. 28-38.

${ }^{20}$ Por. P. Skuza, Ruiny wielkich narracji, remanent idei i recykling projektów, „Albo Albo. Problemy Psychologii i Kultury" 2 (2004), s. 127-131. 
a nie związane już z prawdą"21. Tymczasem dogłębna analiza egzystencjalnej sytuacji człowieka i najgłębszych jego tęsknot wskazuje, że

człowiek potrzebuje poznania, potrzebuje prawdy, ponieważ bez niej nie ma oparcia, nie idzie naprzód. Wiara bez prawdy nie zbawia, nie daje pewności naszym krokom. Pozostaje piękną baśnią, projekcją naszych pragnień szczęścia, czymś, co nas zadowala jedynie w takiej mierze, w jakiej chcemy ulegać iluzji. Albo sprowadza się do pięknego uczucia, które daje pociechę i zagrzewa, ale uzależnione jest od zmienności naszego ducha, zmienności czasów, niezdolne podtrzymywać na stałej drodze w życiu ${ }^{22}$.

Bardzo ważna encyklika papieża Franciszka jest wielowątkowa. W artykule przedstawiono tylko pewne kwestie, by zainspirować do podjęcia dalszych analiz przez przedstawicieli innych dziedzin nauki. Ten bogaty tekst podejmuje bowiem zasadnicze pytania, przed jakimi staje poszukujący współczesny człowiek. Zapoznając się z tekstem, może on podziwiać bogactwo wiary religijnej, która w miłości Bożej objawionej w Jezusie Chrystusie dostrzega swój fundament i staje się światłem.

Papieskie analizy fenomenu wiary mają też znaczenie ogólnospołeczne i cywilizacyjne, bowiem wskazują na historyczne oraz współczesne konsekwencje zagubienia wartości wiary i swoiste zaślepienie możliwościami ludzkiego rozumu. Skutki tego widać głównie w niewłaściwych relacjach społecznych, zagubieniu poczucia własnej tożsamości czy banalizacji życia, które staje się coraz bardziej bezcelowe i beznadziejne, bo nie jest zakorzenione w wierze, nadziei i miłości.

\section{Summary}

\section{Psychological aspects in encyclical Lumen fidei}

The author is convinced, that the first Encyclical of Pope Francis Lumen Fidei (Light of Faith) offers a profound and comprehensive meditation on the role of faith in our live. The Pope writes, that the light of faith comes from God and is able to illuminate all aspects of man's existence: it proceeds from the past, from the memory of Jesus' life, but also comes from the future as it opens up vast horizons.

In the present article the phenomenon of light and dynamics of faith are analysed from the psychological point of view.

\section{Keywords}

Dynamics of faith, function of religion, image of God, phenomenology of light

\footnotetext{
${ }^{21}$ LF 27.

${ }^{22}$ LF 24.
} 
